The role of molecular weight in the enzyme-inhibiting effect of phenolics: the significance in peatland carbon sequestration

Dunn, Christian; Freeman, Christopher

\title{
Ecological Engineering
}

DOI:

10.1016/j.ecoleng.2017.06.036

Published: 15/04/2018

Peer reviewed version

Cyswllt i'r cyhoeddiad / Link to publication

Dyfyniad o'r fersiwn a gyhoeddwyd / Citation for published version (APA):

Dunn, C., \& Freeman, C. (2018). The role of molecular weight in the enzyme-inhibiting effect of phenolics: the significance in peatland carbon sequestration. Ecological Engineering, 114, 162166. https://doi.org/10.1016/j.ecoleng.2017.06.036

\footnotetext{
Hawliau Cyffredinol / General rights

Copyright and moral rights for the publications made accessible in the public portal are retained by the authors and/or other copyright owners and it is a condition of accessing publications that users recognise and abide by the legal requirements associated with these rights.

- Users may download and print one copy of any publication from the public portal for the purpose of private study or research.

- You may not further distribute the material or use it for any profit-making activity or commercial gain

- You may freely distribute the URL identifying the publication in the public portal ?
}

Take down policy

If you believe that this document breaches copyright please contact us providing details, and we will remove access to the work immediately and investigate your claim. 
Engineering

Elsevier Editorial System(tm) for Ecological

Manuscript Draft

Manuscript Number:

Title: The role of molecular weight in the inhibitory effect of phenolics; the significance in peatland carbon sequestration

Article Type: SI: Wetlands and Carbon

Keywords: Molecular weight; phenolics; enzymic latch; peatlands; decomposition; hydrolases

Corresponding Author: Dr. Christian Dunn,

Corresponding Author's Institution: Bangor University

First Author: Christian Dunn

Order of Authors: Christian Dunn; Chris Freeman

Abstract: Northern peatlands store $455 \mathrm{Pg}$ of carbon - a third of the entire global carbon store. Carbon accumulates because phenolic inhibitors slow the rate of decomposition to below that of photosynthetic production. The disproportionate importance of phenolics in peatlands is related to the unique properties of waterlogged peat soils suppressing the activity of phenol oxidase; one of the few enzymes capable of breaking these inhibitors down. This permits accumulation of phenolic compounds that are potent inhibitors of hydrolase enzymes - major agents in the breakdown of organic matter. In our study we investigate the importance of molecular weight of natural phenolic inhibitors on microbial decomposition in peat. We found the higher the molecular weight, of a phenolic compound, the greater its inhibitory effect on the breakdown of organic matter. 
Dear Sir,

We would like to offer our manuscript entitled: "The role of molecular weight in the inhibitory effect of phenolics; the significance in peatland carbon sequestration", for the special Wetlands and Carbon edition of Ecological Engineering.

Yours sincerely

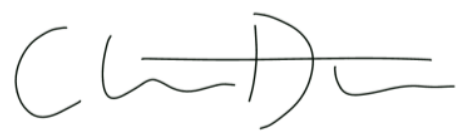

Dr Christian Dunn 


\section{Research highlights}

- $\mathrm{CO}_{2}$ fluxes from peat slurries were inversely related to the molecular weight of the added phenolic material.

- $\mathrm{CH}_{4}$ fluxes from peat slurries were largely unaffected by the molecular weight of the added phenolic material.

- The higher the molecular weight of a phenolic compound the greater its inhibitory effect on the breakdown of organic matter. 


\title{
The role of molecular weight in the inhibitory effect of phenolics; the significance in peatland carbon sequestration
}

\section{Christian Dunn $^{1}$ and Chris Freeman ${ }^{1}$}

${ }^{1}$ Bangor Wetlands Group, The Wolfson Carbon Capture Laboratory, School of Biological Sciences, Bangor University, Deiniol Road, Bangor, Gwynedd, LL57 2UW, United Kingdom. * To whom correspondence should be addressed c.dunn@bangor.ac.uk, +44 (0) 1248 351351.

\begin{abstract}
Northern peatlands store $455 \mathrm{Pg}$ of carbon - a third of the entire global carbon store. Carbon accumulates because phenolic inhibitors slow the rate of decomposition to below that of photosynthetic production. The disproportionate importance of phenolics in peatlands is related to the unique properties of waterlogged peat soils suppressing the activity of phenol oxidase; one of the few enzymes capable of breaking these inhibitors down. This permits accumulation of phenolic compounds that are potent inhibitors of hydrolase enzymes - major agents in the breakdown of organic matter. In our study we investigate the importance of molecular weight of natural phenolic inhibitors on microbial decomposition in peat. We found the higher the molecular weight, of a phenolic compound, the greater its inhibitory effect on the breakdown of organic matter.
\end{abstract}

Key words: Molecular weight; phenolics; enzymic latch; peatlands; decomposition; hydrolases 


\section{Introduction}

Peatlands are unbalanced ecosystems where rates of production exceed levels of decomposition, leading to accretion of around $455 \mathrm{Pg}$ of carbon $\left(1 \mathrm{Pg}=10^{15} \mathrm{~g}\right)$ in the northern hemisphere (Gorham 1991, Limpens, et al. 2008). Traditionally, this impaired decay was attributed to the general anoxia (Gorham 1991, McLatchey and Reddy 1998), low nutrients, low temperatures and low pH associated with peat soils (Gorham 1991, Laiho 2006). But it is now believed that constraints, such as oxygen, on phenol oxidase enzymes is the latch which keeps this vast carbon stock 'locked-up' and prevents it from being released from these wetlands in gaseous or fluvial forms (Fenner and Freeman 2011, Freeman, et al. 2001a, Freeman, et al. 2001b).

Phenol oxidases are among the few enzymes able to fully degrade phenolic compounds (McLatchey and Reddy 1998) so any suppression of their activity allows the build-up phenolics. These compounds in the peat (dead organic matter) have the ability to inhibit the main agents of carbon and nutrient cycling, hydrolase enzymes, from carrying out normal decay processes of soil organic matter (SOM) (Freeman, et al. 2001b, Wetzel 1992). Extracellular enzymes, such as hydrolase enzymes which are produced by a range of bacteria (Fenner, et al. 2005) and fungi (Burke and Cairney 2002), are the primary means by which soil microbes degrade complex organic compounds into smaller molecules they can assimilate. In addition to allowing microbes to access energy and nutrients present in complex substrates, extracellular enzymes catalyse the initial, rate-limiting step of decomposition and nutrient mineralisation (Burns 1982, Sinsabaugh 1994). This dual role of enzymes in soils means that changes in enzyme activities and production can affect ecosystem processes directly. 
Phenolics are a class of chemical compounds consisting of a hydroxyl functional group $(-\mathrm{OH})$ bonded directly to an aromatic hydrocarbon group, consisting of six carbon atoms attached to the same number of hydrogen atoms $\left(\mathrm{C}_{6} \mathrm{H}_{6}\right)$, known as a benzene ring. The simplest of the class is carbolic acid, $\mathrm{C}_{6} \mathrm{H}_{5} \mathrm{OH}$, which is often referred to as phenol. Phenolic compounds are classified as simple phenols or polyphenols based on the number of phenol units in the molecule.

A wide variety of phenolic compounds are produced as secondary metabolites by plants; they include phenolic acids, flavonoids, tannins and the less common stilbenes and lignans. There are currently more than 8,000 known phenolic structures found in plants, ranging from the simple molecules of phenolic acids to the highly polymerised substances such as tannins (Dai and Mumper 2010). Phenolic acids can be divided into two classes: derivatives of benzoic acid such as gallic acid, and derivatives of cinnamic acid such as coumaric, caffeic and ferulic acid. Tannins are usually also subdivided into two groups; 1) hydrolysable tannins and 2) condensed tannins. Hydrolysable tannins are compounds containing a central core of glucose or another polyol esterified with gallic acid, also called gallotannins, or with hexahydroxydiphenic acid, also called ellagitannins (Dai and Mumper 2010). Lignin is the most common member of the flavonoids and is an essential component of wood. It has a highly complex macromolecule that occurs in the plant cell wall and is associated with cellulose and hemicellulose (Faulon and Hatcher 1994).

Amongst many other functions, plants need phenolics for pigmentation, growth, reproduction and resistance to pathogens (Lattanzio, et al. 2006). However, it is the role phenolics play as regulators of soil processes, in terms of their inhibitory effects on extracellular hydrolase enzymes controlling decomposition and nutrient cycling (Freeman, et al. 2001b), that is crucial to peat formation and stability, and the topic of this study. 
Although peatlands currently act as a net sink for atmospheric carbon (Kayranli, et al. 2010) and crucially unlike other ecosystems (such as forests), they are potent long term repositories for carbon (Holden 2005), the breakdown of organic matter $(\mathrm{OM})$ to carbon dioxide $\left(\mathrm{CO}_{2}\right)$ and methane $\left(\mathrm{CH}_{4}\right)$ still occurs, to varying degrees, especially in disturbed and damaged peats (Kayranli, et al. 2010).

We suggest that supplementing peat soil with phenolics using a range of different molecular weight phenolic compounds will provide information on differences in their inhibitory effect on extracellular hydrolase enzymes in peat slurries taken from an ombotrophic blanket bog in the UK. This, we hypothesise, will modify rates of OM breakdown changing gaseous effluxes of carbon-based trace gases, namely the $\mathrm{CO}_{2}$ and $\mathrm{CH}_{4}$ released from microbial respiration.

\section{Methods}

Peat samples for the experiments were taken from the Migneint Valley in North Wales, UK. $\left(3^{\circ} 48.8^{\prime} \mathrm{W}, 52^{\circ} 59.6^{\prime} \mathrm{N}\right)$. The area is a $200 \mathrm{~km}^{2}$ Special Area of Conservation, incorporating one of the largest areas of blanket bog in Wales. Peat for the experiments were collected between June and September (summer). Soil samples (>200g), from a depth of 50 to $100 \mathrm{~mm}$, were taken (by the use of a hand trowel to excavate small pits) from five different locations within $25 \mathrm{~m}^{2}$ of each other with similar above-ground plant species composition, peat-composition, water-table level and microtopography. Samples were placed in sealable plastic bags and transported to the laboratory in a cooled, insulated container. The field temperature of the ground at the location of sample collection was recorded. Back in the laboratory the soil samples were amalgamated, homogenised thoroughly by hand, and had any adhering debris and macroinvertebrates removed from them. They were kept in an 
incubator at the recorded field temperatures before beginning the experiments within 24 hours of collection.

A series of 50:50 peat-solution slurries were created in 50mL centrifuge and consisted of $10 \mathrm{~g}$ samples of peat (which had previously been homogenised by hand for 10 minutes) and $10 \mathrm{~mL}$ of the relevant treatment solution. For the control slurries this solution consisted of ultra-pure water and the phenolic treatment slurries consisted of a $5 \%$ weight/volume $(\mathrm{w} / \mathrm{v})$ solution of ultra-pure water with one of the following dissolved into it (eg. $50 \mathrm{~g}$ in $1,000 \mathrm{~mL}$ ): cinnamic acid (molecular weight, $\left.\mathrm{M}_{\mathrm{W}}, 148.16\right)$, gallic acid $\left(\mathrm{M}_{\mathrm{W}} 170.12\right)$; flavone $\left(\mathrm{M}_{\mathrm{W}}\right.$ 222.24), tannic acid $\left(\mathrm{M}_{\mathrm{W}}=1,701.20\right)$, sodium lignosulphonate acid $\left(\mathrm{M}_{\mathrm{W}} 8,000\right)$, sodium lignosulphonate acid, $\left(\mathrm{M}_{\mathrm{W}}\right.$ 12,000) or calcium lignosulphonate acid $\left(\mathrm{M}_{\mathrm{W}}\right.$ 49,100). These compounds were chosen as although they are all natural-based products, which can be found in organic matter, the refined experimental compounds are all inexpensive and commercially available. A 5\% w/v solution of the phenolic compounds was used following the success of initial concentration experiments and the fact this was considered a maximum useable concentration, taking into account the ability of the compounds to dissolve in water.

To maintain anaerobic conditions the slurries were then immediately placed in a zipper lock-style AtmosBag glove bag (Sigma Aldrich Ltd, Dorset, UK), the air was evacuated with a vacuum pump and oxygen-free-nitrogen was used to re-fill the bag. This process was repeated every 24 hours and the bag regularly checked for holes. The AtmosBag and the slurries were kept in dark conditions at a stable temperature consistent with the recorded temperature of the soil during sample collection.

To measure the microbial respiration from the peat slurries carbon-based gas fluxes $\left(\mathrm{CO}_{2}\right.$ and $\left.\mathrm{CH}_{4}\right)$ were measured after the samples had been incubated under the experimental conditions for 24 hours. Fluxes were calculated with an initial background gas sample (T-1) 
was collected from inside the centrifuge tubes containing the slurries, before lids - with a size nine Suba-Seal rubber septa (Sigma Aldrich Ltd, Dorset, UK) through their centre - were secured onto the tubes, forming an air-tight seal. 60 minutes later a $10 \mathrm{~mL}$ gas sample (T-2) was taken from the headspace of the centrifuge tubes through the septa - after a series of preliminary tests showed that $\mathrm{CO}_{2}$ and $\mathrm{CH}_{4}$ concentrations increased linearly for up to 60 minutes.

Gas samples were analysed by gas chromatography using a Varian model 450 gas chromatograph (GC) instrument, equipped with a flame ionisation detector (FID) with a $\mathrm{CO}_{2}$ to $\mathrm{CH}_{4}$ catalytic converter (methaniser), to measure concentrations of $\mathrm{CO}_{2}$ and $\mathrm{CH}_{4}$. Two millilitres of gas from the Exetainers containing the samples was injected via a 1041 oncolumn injector system, set at $40^{\circ} \mathrm{C}$ onto a PoroPak QS (1.83m x 3.18mm) 80/100 column. The column oven temperature was set to $40^{\circ} \mathrm{C}$ and the carrier gas, oxygen free nitrogen, had a flow rate of $30 \mathrm{~mL} \mathrm{~min}^{-1}$. The temperature of the methaniser was $300^{\circ} \mathrm{C}$ and the FID was at $125^{\circ} \mathrm{C}$. The latter had a hydrogen flow of $25 \mathrm{~mL} \mathrm{~min}^{-1}, 20 \mathrm{~mL} \mathrm{~min}^{-1}$ make-up gas (oxygen free nitrogen) and $300 \mathrm{~mL} \mathrm{~min}^{-1}$ of compressed air. The methaniser had a hydrogen flow of $5 \mathrm{~mL}$ $\min ^{-1}$.

The activity of a range of hydrolase enzymes (namely; $\beta$-D-glucosidase, sulphatase, $\beta$-D-xylosidase, N-acetyl-B-D-glucosaminidase and phosphatase) was calculated from a series of peat slurries made with varying concentrations of $\mathrm{Ca}$ lignosulphonate using the protocol as outlined by Dunn et al. (2014). These slurries were made and stored in the same way as described before, and were left for 24 hours before the assays were conducted.

Relationships between variables were measured using Pearson's correlation coefficient $(r)$, while significant differences between results were determined by independent 
$t$-tests. All statistical tests were performed using PASW Statistics 18 (currently IBM SPSS; IBM Corporation, New York, USA).

\section{Results}

From Figure $1 \mathrm{~A}$ it can be seen that the average $\mathrm{CO}_{2}$ fluxes from peat slurries were inversely related to the molecular weight of the added phenolic material, following 24 hours of incubation. This negative correlation is modest (Taylor 1990) but highly significant ( $r=-$

0.554, $p$ (one-tailed $)=0.001)$. A one-tailed independent t-test also showed there was a significant difference $(t(6)=9.715, p<0.001)$ with a large effect size $r=0.94$ between the $\mathrm{CO}_{2}$ flux of the control slurries and those containing the $\mathrm{Ca}$ Lignosulphonate acid. Although $\mathrm{CH}_{4}$ fluxes from the same slurries, showed a similar negative correlation with molecular weight (Figure 1B), the Pearson's correlation coefficient showed that this was not statistically significant: $r=-0.268, p$ (one-tailed) $=0.084$.

When varying concentrations of a Ca Lignosulphonate acid solution were added to peat to form slurries, and incubated for 24 hours, all the hydrolase enzyme activities (except for $\beta$-D-xylosidase: $r=-0.081, p($ one-tailed $)=0.388)$ showed a statistically significant negative correlation with the solutions' concentration (Figure 2): $\beta$-D-glucosidase, $r=-0.854$, $p($ one-tailed $)<0.001 ;$ sulphatase, $r=-0.666, p$ (one-tailed) $=0.003 ;$ N-acetyl-B-Dglucosaminidase, $r=-0.447, p$ (one-tailed $)=0.047$; phosphatase, $r=-0.557, p$ (one-tailed $)=$ 0.015. An independent one-tailed $t$-test of the control slurries $(0 \% \mathrm{w} / \mathrm{v})$ and those containing a $5 \% \mathrm{w} / \mathrm{v}$ Ca Lignosulphonate solution indicated there was statistically significant difference between the enzyme activities of $\beta$-D-glucosidase $(t(4)=10.072, p<0.001)$, sulphatase $(t$ $(4)=15.989, p<0.001)$ and phosphatase $(t(4)=4.006, p=0.008)$. All three showed a reduction in activity when the phenolic compound was present at this concentration; $\beta$-Dglucosidase by $78 \%$, sulphatase by $96 \%$ and phosphatase by $52 \%$. N-acetyl- $\beta$-D- 
glucosaminidase showed a gradual increase in enzyme activity as the concentration of the $\mathrm{Ca}$ Lignosulphonate supplement rose to $3 \% \mathrm{w} / \mathrm{v}$, however concentrations above this retarded activity; with a $5 \% \mathrm{w} / \mathrm{v}$ concentration reducing activity by $11 \%$ compared to the control, although this was not statistically significant $(t(4)=0.514, p=0.317)$. Similarly, $\beta$-Dxylosidase activities increased with concentration until 3\% w/v before declining, but this time a $5 \% \mathrm{w} / \mathrm{v}$ concentration did not lower activities below that of the control, though the $35 \%$ increase was not statistically significant $(t(4)=-2.401, p=0.074)$.

\section{Discussion}

In this study we aimed to discover if the molecular weight of supplementary phenolic compounds added to the peat matrix could influence the strength of the enzymic latch (Freeman, et al. 2001b): modifying SOM decomposition by the degree of suppression of extracellular enzyme activities, resulting in modified rates of carbon-based trace gas production $\left(\mathrm{CO}_{2}\right.$ and $\left.\mathrm{CH}_{4}\right)$ and therefore net sequestration of carbon as SOM. In the initial slurry experiments a range of phenolic compounds were made into a $5 \% \mathrm{w} / \mathrm{v}$ solution with pure-water and added to peat, taken from the most microbially-active depth of a blanket bog (Freeman, et al. 1995). The phenolic types chosen were all commercially available, synthesised-versions of naturally occurring phenolic compounds associated with vascular plant metabolism or degradation (Hattenschwiler and Vitousek 2000, Lattanzio, et al. 2006).

Our initial experiment indicated that the presence of phenolics did indeed affect the release of trace gases from the peat slurries (Figure 1). Samples containing $\mathrm{Ca}$ lignosulphonate showed the greatest suppression of both $\mathrm{CO}_{2}$ and $\mathrm{CH}_{4}$ compared to a set of control slurries (with no additional phenolics), though only the former was statistically significant. Figure 1 also showed that there was a moderate negative correlation between molecular weight $\left(\mathrm{M}_{\mathrm{w}}\right)$ of the phenolic compounds and $\mathrm{CO}_{2}$ efflux, which corroborates 
previous studies which have shown organic matter $(\mathrm{OM})$ with a high molecular weight (>1,000 apparent $\mathrm{M}_{\mathrm{w}}$ distribution) can inhibit the metabolism of low $\mathrm{M}_{\mathrm{w}} \mathrm{OM}$ (Freeman and Lock 1992, Freeman, et al. 1990). The lignin, Ca lignosulphonate, had the highest $\mathbf{M}_{\mathrm{w}} 49,100$ Daltons (Da) and also had the lowest effluxes of both $\mathrm{CO}_{2}$ and $\mathrm{CH}_{4}$ (though only the former was statistically significant compared to the control samples). It was surprising that lignin appeared to have the greatest effect on $\mathrm{SOM}$ decomposition (if $\mathrm{CO}_{2}$ production is taken as a proxy), as although lignin is the most stable of the polyphenols it is tannin which has previously been suggested is the principle controller over decompositional dynamics (Horner, et al. 1988). However, in this study the tannin used did not significantly lower $\mathrm{CO}_{2}$ production.

The low trace gas fluxes from slurries containing $\mathrm{Ca}$ lignosulphonate, which we observed, can be attributed to the inhibitory effect the lignin had on extracellular hydrolase enzyme activities in the peat slurries (Figure 2), a characteristic that has been well documented in peatlands (eg. Freeman, et al. 2001a, Freeman, et al. 2001b). The phenolic compounds form complexes with protein molecules, serving as polydentate ligands, causing inactivation of the hydrolase enzymes through competitive and non-competitive inhibition (Wetzel 1992). The polyphenols can also bind to the reactive sites of proteins and other organic and inorganic substrates rendering them inactive to further chemical activity and biological attack (Muscolo and Sidari 2006). Suppressing degradation in this way therefore prevents microbial respiration and the resulting release of trace gases. It is important though to note that no work was done to consider any potential effect the calcium or sodium ions, as part of the various lignosulphonate compounds, were having on the biogeochemistry of the peat samples. It is likely they will affect the ion concentrations of the peat slurries so this needs to be investigated more fully. 
Our results showed that the activity of several hydrolase enzymes were severely curtailed by the presence of a $5 \% \mathrm{w} / \mathrm{v}$ Ca lignosulphonate solution, including $\beta$-Dglucosidase which are involved in the generation of labile glucose from cellulose (Deng and Popova 2011), and so key in determining microbial activity and therefore $\mathrm{CO}_{2}$ efflux from peat soils. The results of the concentration test (Figure 2) suggest that a $5 \% \mathrm{w} / \mathrm{v} \mathrm{Ca}$ lignosulphonate solution is required to significantly inhibit $\mathrm{OM}$ degradation and $\mathrm{CO}_{2}$ release. Higher concentrations of $\mathrm{Ca}$ lignosulphonate solution were not tested due to the difficulty of getting the lignin into solution and the wish to keep the concentration to practical and inexpensive amounts, should we wish to apply it on a larger field scale.

Interestingly, both $\beta$-D-xylosidase and $\mathrm{N}$-acetyl- $\beta$-D-glucosaminidase activities increased with $\mathrm{Ca}$ lignosulphonate concentration up to $3 \% \mathrm{w} / \mathrm{v}$, and the former's activities remained higher at $5 \% \mathrm{w} / \mathrm{v}$ than those of the control slurries. The supplementary lignin was not therefore able to suppress all enzymic activity, which could be due to the selective and specialist nature of hydrolase enzymes enabling them to use different substrates across a wide range of environments (Allison and Vitousek 2004, Lee, et al. 1999, Nybroe, et al. 1992).

Previous work has shown that $\mathrm{pH}$ plays an important role in carbon cycling (Bergman, et al. 1998, Dunfield, et al. 1993) and maybe even the enzymic latch in peatlands (Williams, et al. 2000,). Although the slurries made with the Ca lignosulphonate solution did have a lower $\mathrm{pH}$, statistical tests suggested this was not significant so it could be predicted that the additional phenolics were the key suppressor of the enzyme activities and resulting GHG effluxes.

The primary question in our study was "does molecular weight influence the inhibitory effects of phenolics and thus the strength of the enzymic latch?" Clearly from our 
results we can conclude that supplementing peat with high molecular weight phenolics can suppress enzyme activity and the consequent release of GHG fluxes (namely $\mathrm{CO}_{2}$ ) from SOM decomposition. Methane release showed a similar trend, but was far less affected by the presence of high molecular weight phenolics. 


\section{References}

Allison SD, Vitousek PM (2004) Extracellular enzyme activities and carbon chemistry as drivers of tropical plant litter decomposition. Biotropica 36: 285-296 doi:

10.1111/j.1744-7429.2004.tb00321.x

Bergman I, Svensson BH, Nilsson M (1998) Regulation of methane production in a Swedish acid mire by $\mathrm{pH}$, temperature and substrate. Soil Biology \& Biochemistry 30: 729-741 doi: 10.1016/s0038-0717(97)00181-8

Brunow G (2001) Methods to reveal the structure of lignin. In: Hofrichter M, Steinbüchel A (eds) Lignin, Humic Substances and Coal (Biopolymers). Wiley-VCH, Weinheim, Germany.

Burke RM, Cairney JWG (2002) Laccases and other polyphenol oxidases in ecto- and ericoid mycorrhizal fungi. Mycorrhiza 1210.1007/s00572-002-0162-0

Burns RG (1982) Enzyme-activity in soil: location and a possible role in microbial ecology. Soil Biology \& Biochemistry 14: 423-427 doi: 10.1016/0038-0717(82)90099-2

Dai J, Mumper RJ (2010) Plant Phenolics: Extraction, Analysis and Their Antioxidant and Anticancer Properties. Molecules 15: 7313-7352 doi: 10.3390/molecules 15107313

Deng S, Popova I (2011) Carbohydrate hydrolases. In: Dick RP (ed) Mehods of soil enzymology. Soil Science Society of America, Inc., Madison, Wisonsin, USA, pp. 185-209.

Dunfield P, Knowles R, Dumont R, Moore TR (1993) Methane production and consumption in temperate and sub-Arctic peat soils - response to temperature and $\mathrm{pH}$. Soil Biology \& Biochemistry 25: 321-326 doi: 10.1016/0038-0717(93)90130-4

Dunn C, Jones TG, Girard A, Freeman C (2014) Methodologies for Extracellular Enzyme Assays from Wetland Soils. Wetlands 34: 9-17 doi: 10.1007/s13157-013-0475-0

Faulon JL, Hatcher PG (1994) Is there any order in the structure of lignin? Energy \& Fuels 8: 402-407 doi: 10.1021/ef00044a018

Fenner N, Freeman C (2011) Drought-induced carbon loss in peatlands. Nature Geoscience 4: 895-900 doi: 10.1038/ngeo1323

Fenner N, Freeman C, Reynolds B (2005) Hydrological effects on the diversity of phenolic degrading bacteria in a peatland: implications for carbon cycling. Soil Biology \& Biochemistry 3710.1016/j.soilbio.2004.11.024

Freeman C, Evans CD, Monteith DT, Reynolds B, Fenner N (2001a) Export of organic carbon from peat soils. Nature 412: 785-785 doi: 10.1038/35090628

Freeman C, Liska G, Ostle NJ, Jones SE, Lock MA (1995) The use of fluorogenic substrates for measuring enzyme-activity in peatlands. Plant and Soil 175: 147-152 doi:

Freeman C, Lock MA (1992) Recalcitrant high-molecular-weight, an inhibitor of microbialmetabolism in river biofilms. Applied and Environmental Microbiology 58: 20302033 doi:

Freeman C, Lock MA, Marxsen J, Jones SE (1990) Inhibitory effects of high-molecularweight dissolved organic-matter upon metabolic processes in biofilms from contrasting rivers and streams. Freshwater Biology 24: 159-166 doi: 10.1111/j.13652427.1990.tb00315.x

Freeman C, Ostle N, Kang H (2001b) An enzymic 'latch' on a global carbon store - A shortage of oxygen locks up carbon in peatlands by restraining a single enzyme. Nature 409: 149-149 doi:

Gorham E (1991) Northern Peatlands - Role in the carbon-cycle and probable responses to climatic warming. Ecological Applications 1: 182-195 doi: 
Hattenschwiler S, Vitousek PM (2000) The role of polyphenols in terrestrial ecosystem nutrient cycling. Trends in Ecology \& Evolution 15: 238-243 doi: 10.1016/s01695347(00)01861-9

Holden J (2005) Peatland hydrology and carbon release: why small-scale process matters. Philosophical Transactions of the Royal Society a-Mathematical Physical and Engineering Sciences 363: 2891-2913 doi: 10.1098/rsta.2005.1671

Horner JD, Gosz JR, Cates RG (1988) The role of carbon-based plant secondary metabolites in decomposition in terrestrial ecosystems. American Naturalist 132: 869-883 doi: $10.1086 / 284894$

Kayranli B, Scholz M, Mustafa A, Hedmark A (2010) Carbon Storage and Fluxes within Freshwater Wetlands: a Critical Review. Wetlands 30: 111-124 doi: 10.1007/s13157009-0003-4

Laiho R (2006) Decomposition in peatlands: Reconciling seemingly contrasting results on the impacts of lowered water levels. Soil Biology \& Biochemistry 38: 2011-2024 doi: 10.1016/j.soilbio.2006.02.017

Lattanzio V, Lattanzio VMT, Cardinali A (2006) Role of phenolics in the resistance mechanisms of plants against fungal pathogens and insects. In: Imperato F (ed) Phytochemistry: advances in research. Research Signpost, Kerala, India, pp. 23-67.

Lee SS, Shin KJ, Kim WY, Ha JK, Han IK (1999) The rumen ecosystem: As a fountain source of nobel enzymes - Review. Asian-Australasian Journal of Animal Sciences 12: $988-1001$ doi:

Limpens J, Berendse F, Blodau C, Canadell JG, Freeman C, Holden J, Roulet N, Rydin H, Schaepman-Strub G (2008) Peatlands and the carbon cycle: from local processes to global implications - a synthesis. Biogeosciences 5: 1475-1491 doi:

McLatchey GP, Reddy KR (1998) Regulation of organic matter decomposition and nutrient release in a wetland soil. Journal of Environmental Quality 27: 1268-1274 doi:

Muscolo A, Sidari M (2006) Seasonal fluctuations in soil phenolics of a coniferous forest: effects on seed germination of different coniferous species. Plant and Soil 284: 305318 doi: 10.1007/s11104-006-0040-1

Nybroe O, Jorgensen PE, Henze M (1992) Enzyme-activities in waste-water and activatedsludge. Water Research 26: 579-584 doi: 10.1016/0043-1354(92)90230-2

Ouyang X, Qiu X, Chen P (2006) Physicochemical characterization of calcium lignosulfonate - A potentially useful water reducer. Colloids and Surfaces a-Physicochemical and Engineering Aspects 282: 489-497 doi: 10.1016/j.colsurfa.2005.12.020

Sinsabaugh RL (1994) Enzymatic analysis of microbial pattern and process. Biology and Fertility of Soils 17: 69-74 doi: 10.1007/bf00418675

Taylor R (1990) Interpretation of the correlation-coefficient - a basic review. Journal of Diagnostic Medical Sonography 6: 35-39 doi: 10.1177/875647939000600106

Wetzel RG (1992) Gradient-dominated ecosystems - sources and regulatory functions of dissolved organic-matter in fresh-water ecosystems. Hydrobiologia 229: 181-198 doi:

Williams CJ, Shingara EA, Yavitt JB (2000) Phenol oxidase activity in peatlands in New York State: Response to summer drought and peat type. Wetlands 2010.1672/02775212(2000)020[0416:poaipi]2.0.co;2

Xiao B, Sun XF, Sun RC (2001) The chemical modification of lignins with succinic anhydride in aqueous systems. Polymer Degradation and Stability 71: 223-231 doi: 10.1016/s0141-3910(00)00133-6 


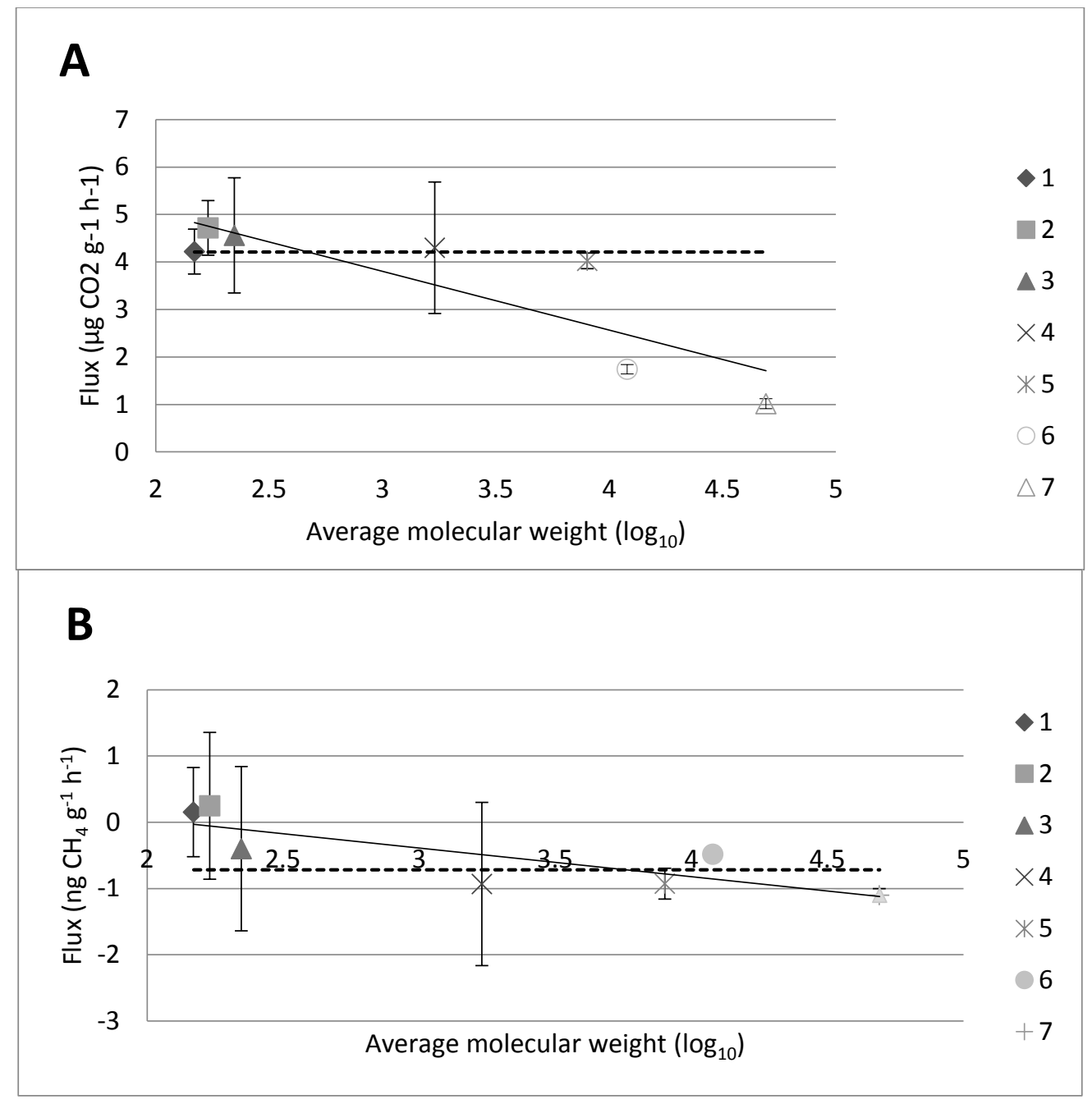

Figure 1. $\mathrm{CO}_{2}$ and $\mathrm{CH}_{4}$ fluxes from peat slurries after 24 hours of having supplementary phenolic compounds added to them. A $5 \% \mathrm{w} / \mathrm{v}$ solution, consisting of the phenolic compound and sterile water, was added to bog peat and made into slurries. These were then incubated in dark, anaerobic conditions for 24 hours before gas fluxes were calculated. Mean average of fluxes $(n=4)$ are shown and error bars indicate \pm standard error. The hatched line represents the mean average $\mathrm{CO}_{2}(\mathbf{A})$ or $\mathrm{CH}_{4}(\mathbf{B})$ flux from control slurries containing no additional phenolic material. $1=$ Cinnamic acid $\left(\mathrm{M}_{\mathrm{W}} 148.16\right) ; 2=$ Gallic acid $\left(\mathrm{M}_{\mathrm{W}}\right.$ 170.12); 3 = Flavone $\left(\mathrm{M}_{\mathrm{W}} 222.24\right) ; 4=$ Tannic Acid $\left(\mathrm{M}_{\mathrm{W}}=1,701.20\right) ; 5=$ sodium lignosulphonate acid $\left(\mathrm{M}_{\mathrm{W}}\right.$ 8,000); 6 = sodium lignosulphonate acid, $\left(\mathrm{M}_{\mathrm{W}} 12,000\right) ; 7=$ Calcium Lignosulphonate acid $\left(\mathrm{M}_{\mathrm{W}} 49,100\right)$. 

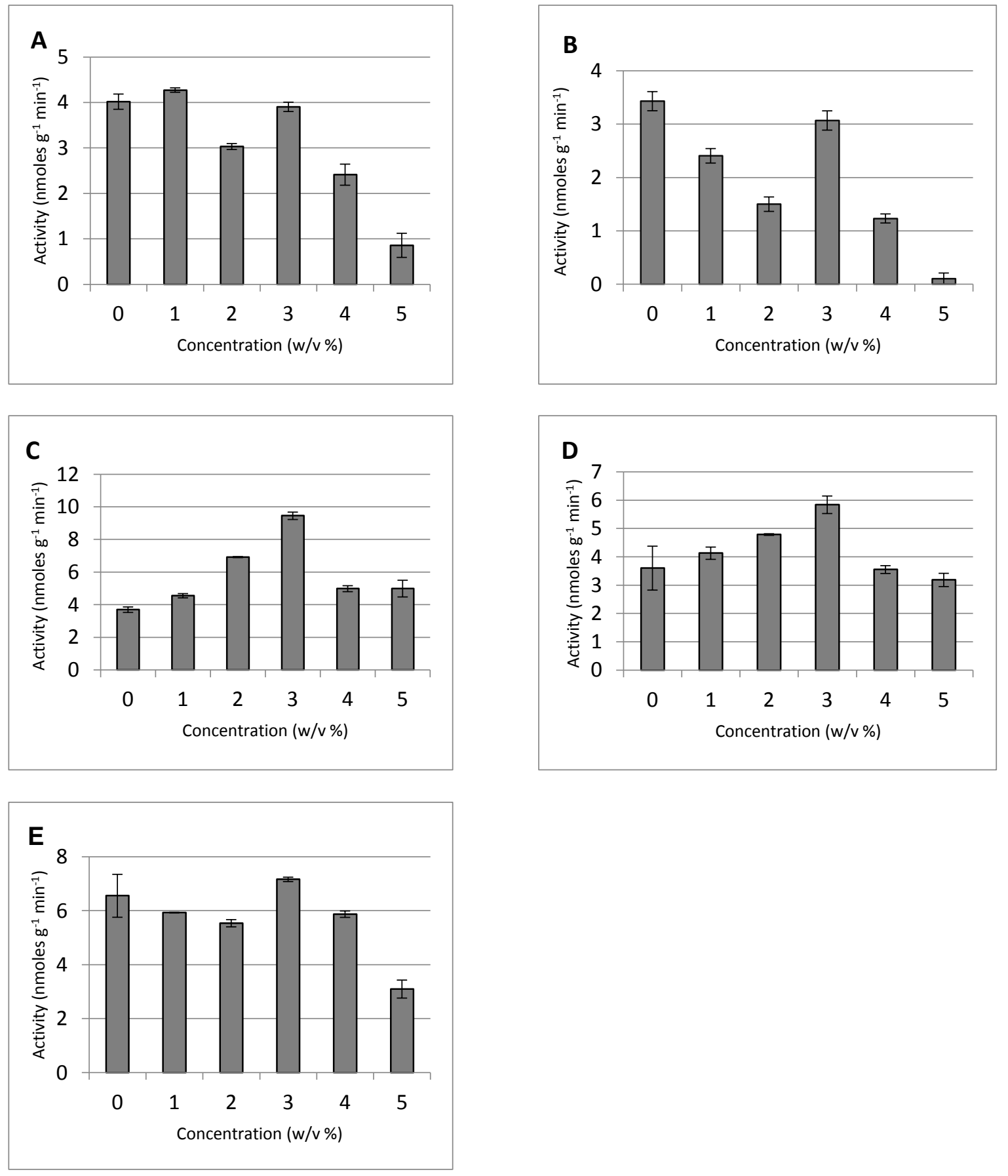

Figure 2. Hydrolase enzyme activities in peat slurries made with different concentrations (w/v \%) of a Ca Lignosulphonate acid solution. Slurries were made with bog peat slurries. They were then incubated in dark, anaerobic conditions for 24 hours before gas fluxes were measured. Mean average of activities $(n=4)$ are shown and error bars indicate \pm standard error. $\mathbf{A}=\beta$-D-glucosidase $\mathbf{B}=$ sulphatase $\mathbf{C}=\beta$-D-xylosidase $; \mathbf{D}=\mathrm{N}$-acetyl-BD-glucosaminidase; $\mathbf{E}=$ phosphatase. 